\title{
Groundwater Chemistry in a Meander Bend of the Polluted Biała Przemsza River
}

\author{
Dariusz Ciszewski* \\ AGH-University of Science and Technology, Kraków, Poland
}

Received: 22 September 2017

Accepted: 4 March 2018

\begin{abstract}
Groundwater chemistry in alluvia was investigated in a meander bend of the Biała Przemsza River in its middle course at Sławków in Upper Silesia, southern Poland. Pollution of groundwater induced by inflow of river water enabled recognition of relative differences in the amount of inflowing water. Biogeochemical zonation is a characteristic feature of the investigated groundwater. Inflow of river water is most intensive in the zone of about $1 / 3$ of the bend width, parallel to the channel. It is characterized by macroions concentrations higher than that in the river. Outside, in the central part of the bend, concentrations of macroions significantly decrease. In this part of the bend, the largest head gradient also is observed. It increases toward the apex, and close to the river channel it equals about $40 \mathrm{~cm}$. Groundwaters in the distal part of the bend are the least mineralized as a result of dilution by rain water. Investigations suggest a slow exchange of the hyporheic waters because of the prevalence of sandy-silty sediments. It favours transformation of nitrates, sulphates, and iron mobility in reducing conditions. Reducing their load in the river can be remarkable over the $30 \mathrm{~km}$ meandering reach of this river.
\end{abstract}

Keywords: hyporheic zone, river, chemical composition, pollution, groundwater

\section{Introduction}

The inflow of river waters into alluvia is considered to be an important factor for transporting pollutants by rivers and their potential degradation due to differences in biogeochemical characteristics of sub-environments of surface- and groundwaters [1]. The area in which this inflow takes place and where river- and groundwaters are mixed is called the hyporheic zone. The inflow of river water may be observed in various spatial scales. In a microform scale of the river bed, single ripplemarks induce the inflow of water in their proximal zone and its

*e-mail: ciszewski@geol.agh.edu.pl outflow in their distal zone. Similarly, single boulders, pebbles, or tree logs may also create increased inflow into the bed [2]. In the meso-scale of the riverbed, the exchange of waters depends on the variability of hydrostatic pressure associated with the occurrence of riffles and bars and the permeability and grain size of sediment buildup [3]. Usually, the inflow of water into the alluvia occurs in their proximal zone; while water flows through them, pollutants are intensely transformed due to changes in redox conditions with the participation of microorganisms and meiofauna. The water that flows out in their distal section usually has a largely reduced content of oxygen and nitrate compounds [4]. Water exchange within the floodplain depends on the width and the depth of the valley bottom, the thickness of alluvia, and channel geometry. Areas of increased 
inflow of river waters in the alluvia of floodplains may be distinguished; they are also referred to as gaining sections [5]. In the losing sections, in turn, the river is supplied with groundwater from the valley, which flows through alluvial deposits [6]. The hyporheic zone of losing and gaining sections of contaminated rivers may be characterized by contrastively different chemical composition of waters [7]. It can stretch from centimeters to even many kilometers in width and reach depths of many meters.

The meandering river stream is conducive to lateral build-up of alluvia. It is characterized by the flow of groundwaters generally in accordance with the slope of the valley bottom [6]. Thus, on its many sections, a meandering river flows perpendicular to the direction of the head gradient, losing water in the upper part of the meander and gaining it in the lower section. Numerous hyporheic flow models demonstrate that meandering belongs to more effective hyporheic water flow drivers [8]. It has been proven that the entire volume of the Mississippi River waters entering the estuary could flow through the hyporheic zone as a result of lateral exchange, and some waters could flow through it even several times [9]. Such a considerable share of lateral exchange of the Mississippi River waters indicates its potential importance for the transportation of biogenic compounds with the river flow, although, for example, as little as $1 / 4$ of the hyporheic zone contributes to denitrification processes. Thus, the hyporheic zone may function as a temporary reservoir for contaminants carried by the river; in the reservoir, contaminants undergo transformation and they may be a source of certain chemicals for waters re-entering the river. Better recognition of its functioning in valleys of polluted rivers enables a more accurate assessment of its importance in reducing pollutant load transported by the river.

The Biała Przemsza River in southern Poland is an example of a heavily contaminated river by waters from a zinc and lead ore mine. The aim of this paper was to estimate the influence of river waters on groundwater chemistry in a meander bend in its middle reach. Thanks to the diversification of the chemical composition of groundwaters and the depth of their level, an active water exchange zone in the bend has been determined and conclusions have been drawn as to the role of this zone in reducing river pollution.

\section{Material and Methods}

\section{Research Area}

The Biała Przemsza River flows out in the limestone area of the Kraków Upland at an altitude of $376 \mathrm{~m}$ a.s.1. It flows through the eastern part of the Silesian Upland and after $66 \mathrm{~km}$ it enters the Przemsza River at an altitude of approx. $250 \mathrm{~m}$ a.s.l. The relief of the valley is characterized by the presence of cuestas, which are made up of Upper Jurassic rocks and Middle and Upper
Triassic rocks. The bottom of the valley within these cuestas is narrow and has a greater fall. In-between are basins formed in Rhaetic sediments of low resistance, filled with sandy fluvioglacial sediments [10]. The river has a natural channel almost along its entire length. In the gorge sections, the river has a straight course, whereas in sections with a smaller fall, it is strongly meandering. In the Biskupi Bor Basin, in the middle of the river, the bottom of the valley extends to more than $1 \mathrm{~km}$ and due to its inconsiderable gradient, it is overgrown with mostly riparian forest or wetland vegetation. Alder carrs or willow trees overgrow the river banks and they have a considerable impact on its stability. The mouths river section is channelized because of the need to reduce the seepage of river water to the nearby coal mine.

The Biała Przemsza River, with a flow rate of about $5.5 \mathrm{~m}^{3} / \mathrm{s}$ at its mouth, receives polluted waters from the zinc and lead ore mine in Bukowno. Dumped mine waters (about $2 \mathrm{~m}^{3} / \mathrm{s}$ ) flow to Biała Przemsza in its middle course via a concrete aqueduct and an old channel of the no longer existing Biała River. When mixed with the waters of the Biała Przemsza River, they flow along with them for nearly 40 kilometers. Below Sławków, the river receives mine waters also via the Sztoła River in the amount of approx. $1 \mathrm{~m}^{3} / \mathrm{s}$. The share of waters from the zinc and lead mine and other industrial waters in the total Biała Przemsza River discharge is considerable and reaches $60 \%$ during low water levels [10]. As a result of water discharge from the mine, river waters and groundwaters are characterized by significantly increased mineralization and their sediments are heavily contaminated with heavy metals [11]. A large proportion of mine waters and the escape of river waters into the underlying aquifer results in lowering the river discharge amplitude [12].

\section{Methods}

Groundwater samples were collected from piezometers installed in the bend of the Biała Przemsza River in the meandering, middle reach of the river downstream of Sławków. The river bend was about 200 meters long and had a width of about $50 \mathrm{~m}$. Twenty-two piezometers at a depth of $2 \mathrm{~m}$ were spaced about $10 \mathrm{~m}$ apart crosswise the meanders: in C-F, G-L, M-R, S-T, and in Ia-IIa-W-U points (Fig. 1). Samples were taken ten times during one hydrologically average year (2014), from piezometers, and from the river. The sampling of water from piezometers after its volume having been pumped out three times was carried out using a peristaltic pump and followed the measurement of the depth of the groundwater table. The level of water in the river was also measured. Water was drawn into 0.51 bottles and into $50 \mathrm{ml}$ containers after filtration and acidification to $\mathrm{pH}=2$. Bottled water was measured for $\mathrm{pH}$ and conductivity (EC). Upon filtration through $0.45 \mu \mathrm{m}$ filters, the concentrations of $\mathrm{Cl}_{-}^{-}, \mathrm{NO}_{3}^{-}, \mathrm{SO}_{4}^{2-}, \mathrm{PO}_{4}^{3-}, \mathrm{CO}_{3}^{2-}$, and macro-ionic 


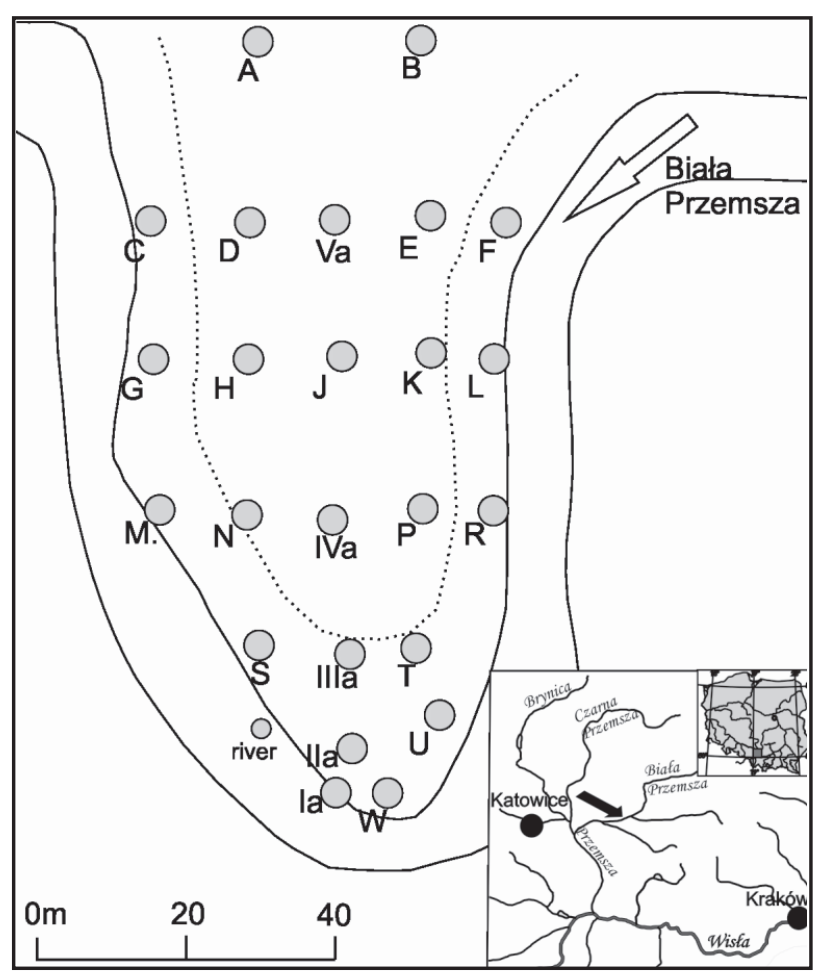

Fig. 1. Location of research area and sampling sites.

concentrations ( $\mathrm{Ca}, \mathrm{Mg}, \mathrm{Na}, \mathrm{K})$ were determined using ion chromatography (DIONEX 1000). In acidified water, concentrations of $\mathrm{Fe}$ and $\mathrm{Zn}$ were determined using ICP MS on a Perkin Elmer ELAN 6100.

\section{Results and Discussion}

\section{Water Chemistry}

The gradient of the water level in the meander bend was established based on average differences between the levels of the highest (F) and the lowest (C) piezometers. These values converged, within 2-3 $\mathrm{cm}$, with the water level in the river in the vicinity of these piezometers. A similar difference was also noted between other piezometers in the proximal (F-L-R) and distal (M-G-C) sections of the meander (Fig. 2). The difference of about $15 \mathrm{~cm}$ accounts for a gradient of about $0.8 \%$, typical of strongly meandering, slowly flowing lowland rivers. However, the average depth of the water table varied in cross-sections through the bend. The water table of the piezometers in the proximal part was similar and clearly fell from the middle of the bend toward the distal section (Fig. 2). The closer to the apex, the more distinct was the lowest water table in the central part of the bend in crosssections. At IIa point, close to the channel, the water level was nearly $40 \mathrm{~cm}$ lower than in the channel located $5 \mathrm{~m}$ away, and it was also lower than its location at neighboring points, e.g., U.
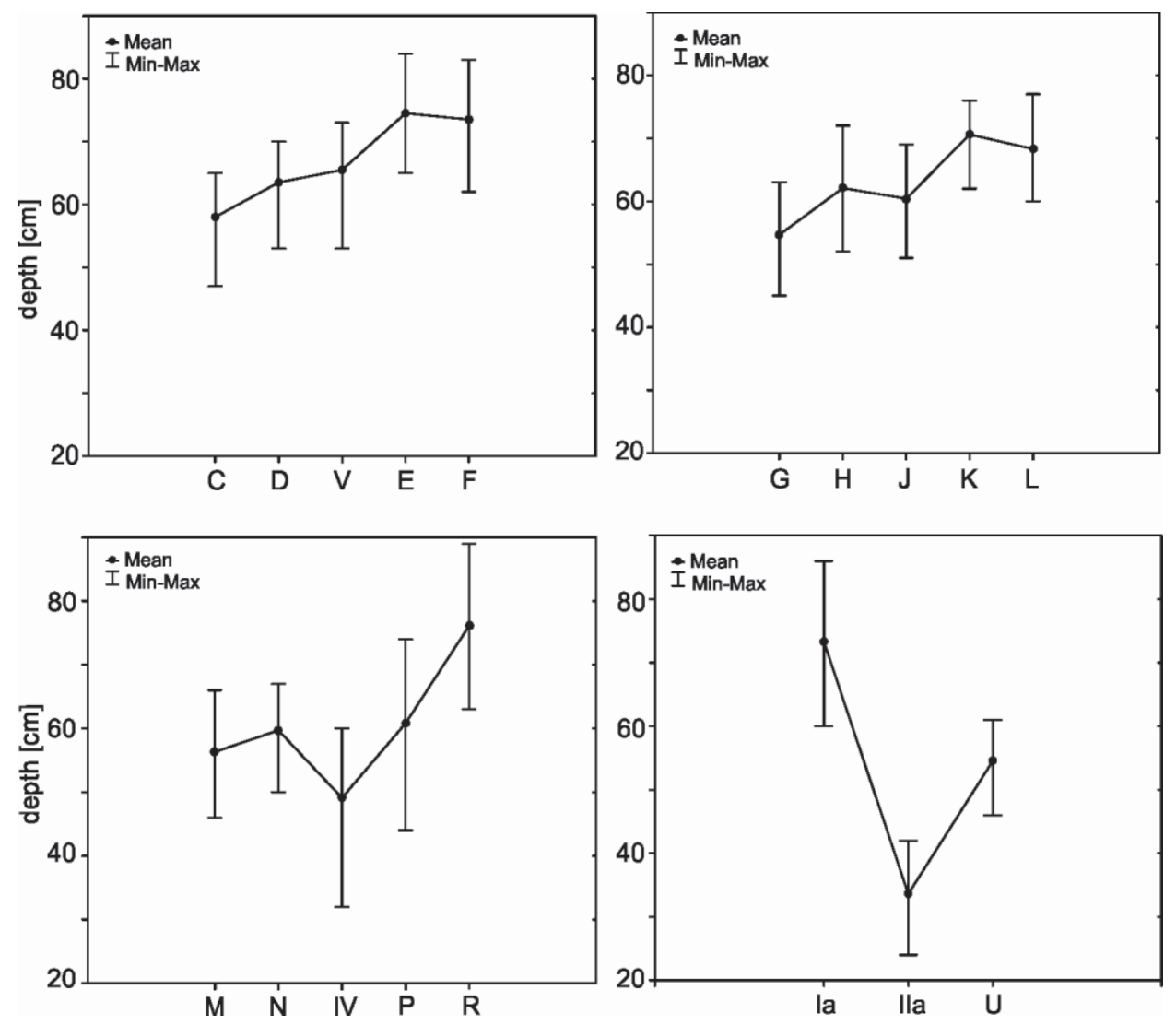

Fig. 2. Mean depths of groundwater table in cross-sections C-F, G-L, M-R, and Ia-U in the investigated period. 


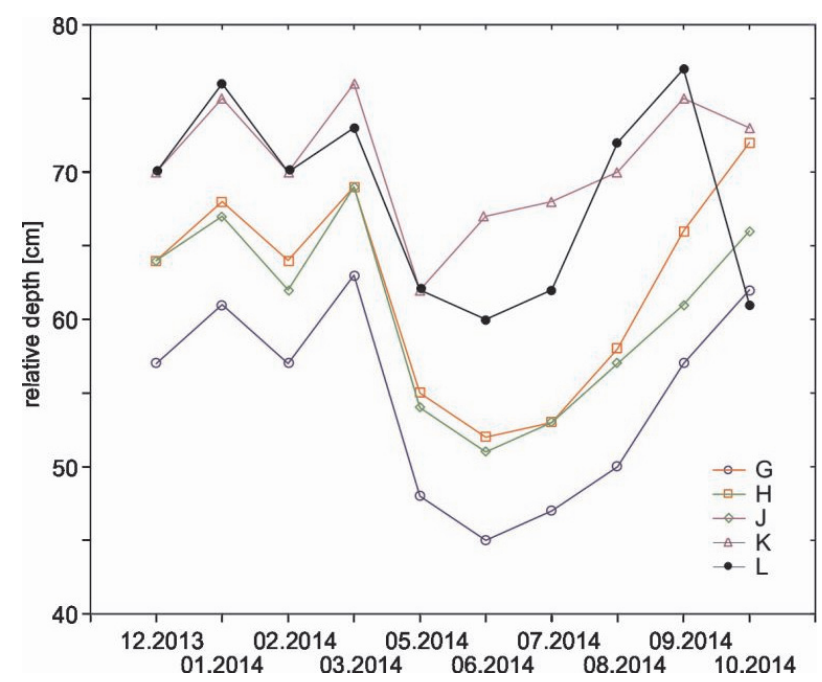

Fig. 3. Changes of the groundwater table in cross-section G-L in the investigated period.

The amplitude of water level fluctuations in all the examined piezometers was generally quite similar and amounted to about $15-20 \mathrm{~cm}$ during the examined year, reaching $25 \mathrm{~cm}$ at some points in the proximal part and in the river channel (Fig. 2). Relative differences in the depth of the water table between the section points were also similar despite the changing intensity of precipitation during the analyzed period. Changes in some points deviating from this regularity were locally specific. $\mathrm{K}$ point may be used as an example here (Fig. 3). In $\mathrm{K}$ point, the water level rose in June and July, and it fell in October much more than in other points of the section. Also, at point Va, fluctuations in the water table were much more distinct from those in adjacent C-F cross-sectional points can be observed, although the differences appear to be only for certain sampling periods (Fig. 4). Similar deviations can also be observed, for example, in points IVa, $\mathrm{P}$, and $\mathrm{M}$, yet they do not exceed $10 \mathrm{~cm}$. However, in general, for the majority of piezometers, the highest water level was observed in September or October 2014, and this was associated with heavy rainfall during the period (total $150 \mathrm{~mm}$ ). Low values were typical of the summer period (Fig. 3).

Although chemical composition of waters does not show any regular changes over the investigated period, clear spatial differences, observed between sampling points, are shown in Figs 5-10. The lowest content of almost all investigated substances and groundwater parameters is observed in piezometers $\mathrm{A}, \mathrm{B}$, and $\mathrm{OO}$ (Fig. 5), but there are also differences between points near the bend (A, B) and at the point near the edge of the valley (OO). Points A and B are characterized by slightly higher $\mathrm{pH}$ and higher contents of $\mathrm{Ca}, \mathrm{Na}$, and $\mathrm{Mg}$, as well as sulfates and bicarbonates than in OO. The difference is usually double and it is reflected in an average conductivity difference of more than $200 \mu \mathrm{S}$. The content of $\mathrm{K}$ is higher near the valley edge, and the concentrations of $\mathrm{Cl}$ are rather similar. The low contents of $\mathrm{Zn}$ and $\mathrm{Fe}$ and higher contents of nitrates are typical of groundwaters at point OO. At point $\mathrm{A}$, the Fe content of nearly $10 \mathrm{mg} / \mathrm{l}$ on average is the highest of all points tested. At point $\mathrm{B}$, the $\mathrm{Zn}$ content of about $0.5 \mathrm{mg} / \mathrm{l}$ is higher than the average value for all waters examined.

$\mathrm{pH}$ values in piezometers of the C-F cross-section vary within relatively low limits of 6.5-7 (Fig. 6). They have the minimum value for all points in June and the maximum is in December at point $\mathrm{C}$. The concentrations of $\mathrm{Ca}$, which is generally between 100 and $150 \mathrm{mg} / \mathrm{l}$, are more diversified. They are clearly the lowest at point VA, usually within the range of 50-80 mg/l. Maximum $\mathrm{Ca}$ content occurs in points in the proximal part of $\mathrm{E}$ and $\mathrm{F}$, reaching up to $170 \mathrm{mg} / \mathrm{l}$ in the autumn of 2014. Larger differences (even several times larger) between points $\mathrm{E}$ and $\mathrm{F}$ and other points are visible for $\mathrm{K}$. In points $\mathrm{D}$ and $\mathrm{VA}$, the values are minimal in the cross-section, usually in the range of $0.5-1 \mathrm{mg} / 1$, while the maximum values at the extreme point $\mathrm{F}$ of the cross-section exceeded $9 \mathrm{mg} / \mathrm{l}$ for half a year. The differences in concentrations of $\mathrm{Mg}$, $\mathrm{Na}$, and $\mathrm{Cl}$ are similar. Their highest contents amount to $30-40 \mathrm{mg} / \mathrm{l}$ on average at points in the proximal part of the bend, whereas values within the limits of 10-30 mg/l occur in other points. Higher conductivity, typically $1000-1100 \mu \mathrm{S}$ in $\mathrm{E}$ and $\mathrm{F}$, is convergent with these differences, whereas values at $\mathrm{C}, \mathrm{D}$, and VA vary from
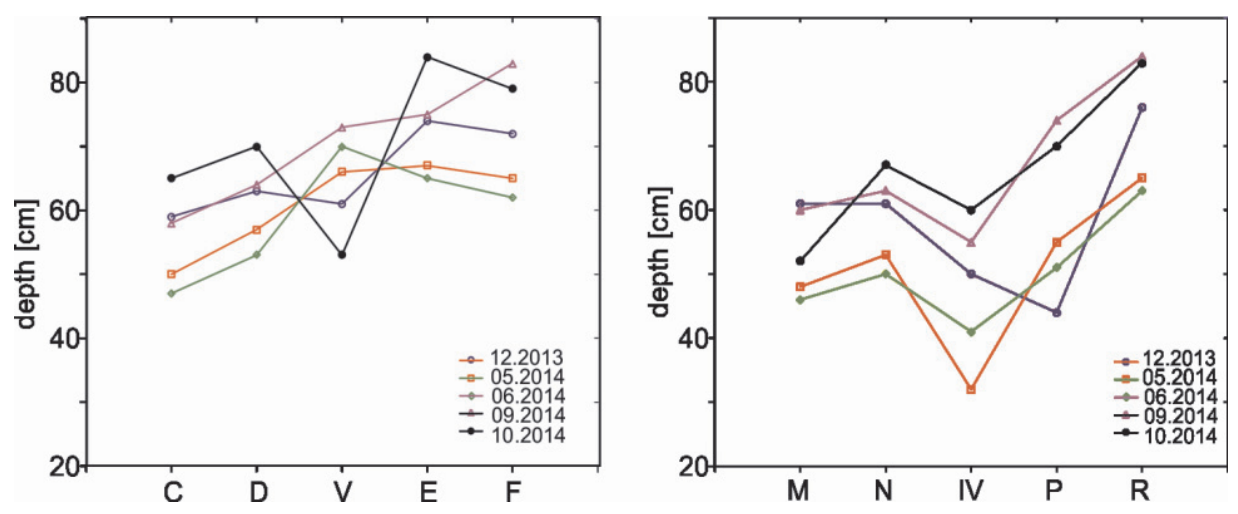

Fig. 4. Changes of the groundwater table in cross-section C-F and M-R in the investigated period. 


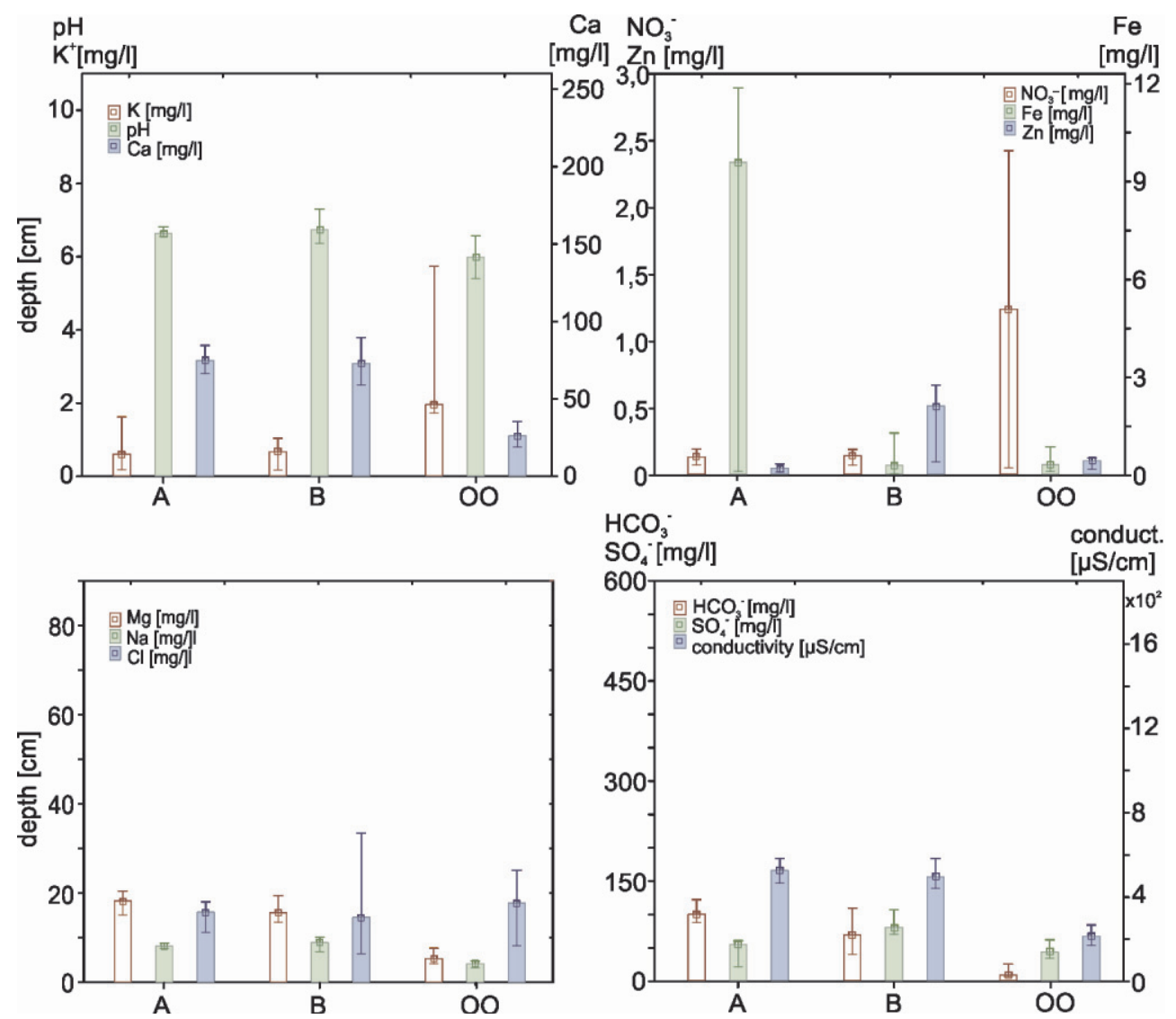

Fig. 5. Concentration variability of investigated features and chemical compounds in groundwater in cross-section A-B and in the reference point 00
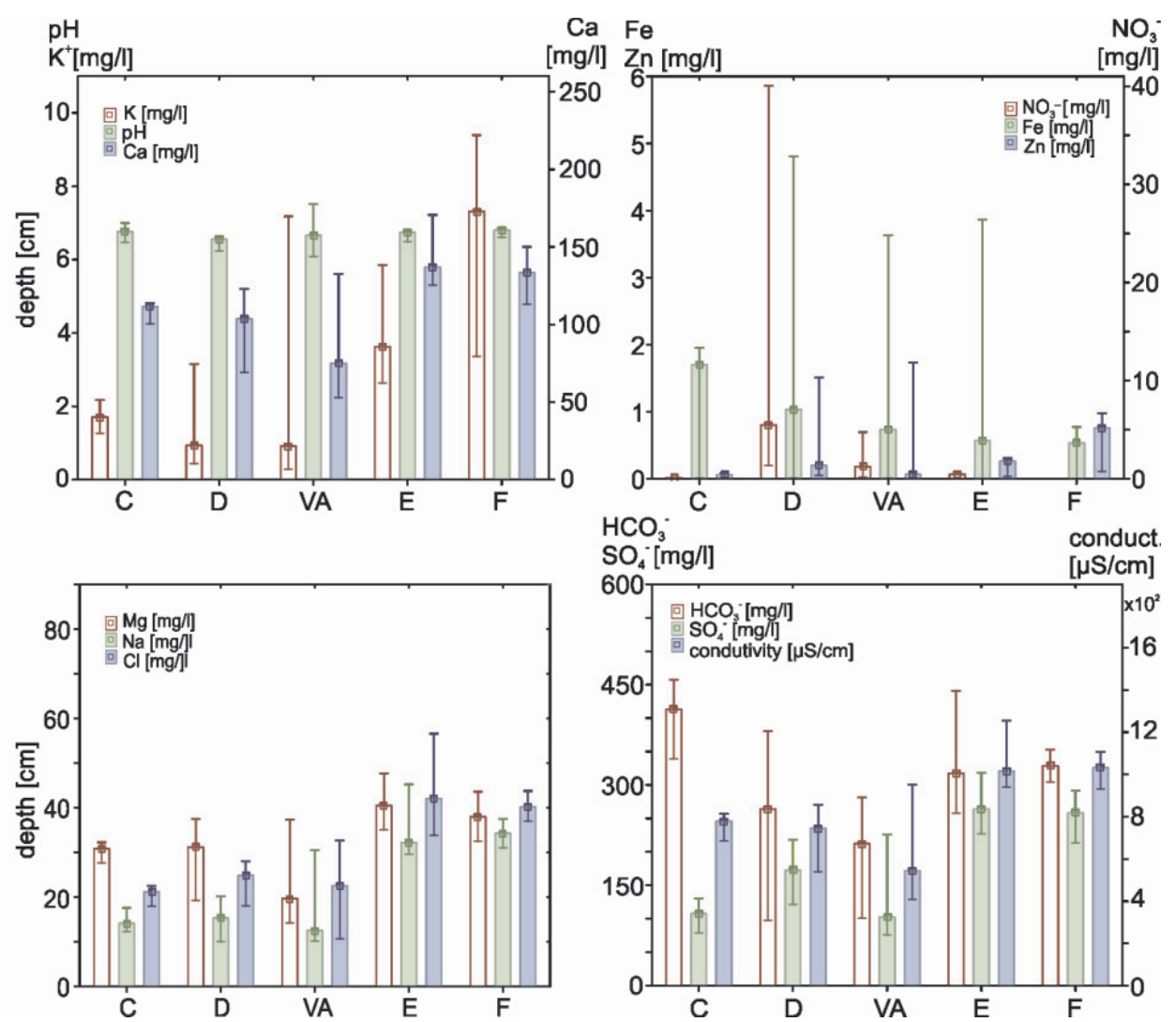

Fig. 6. Concentration variability of investigated features and chemical compounds in groundwater in cross-section C-F 
400 to $800 \mu \mathrm{S}$. Sulfate differentiation is also similar. High values (about $230-320 \mathrm{mg} / \mathrm{l}$ ) of sulfates occur in $\mathrm{E}$ and $\mathrm{F}$, while values of $80-130 \mathrm{mg} / \mathrm{l}$ are observed in points $\mathrm{C}$ and VA. This is different for bicarbonates due to their higher content of about $350-450 \mathrm{mg} / \mathrm{l}$ at point $\mathrm{C}$ in the distal section and minor differences between
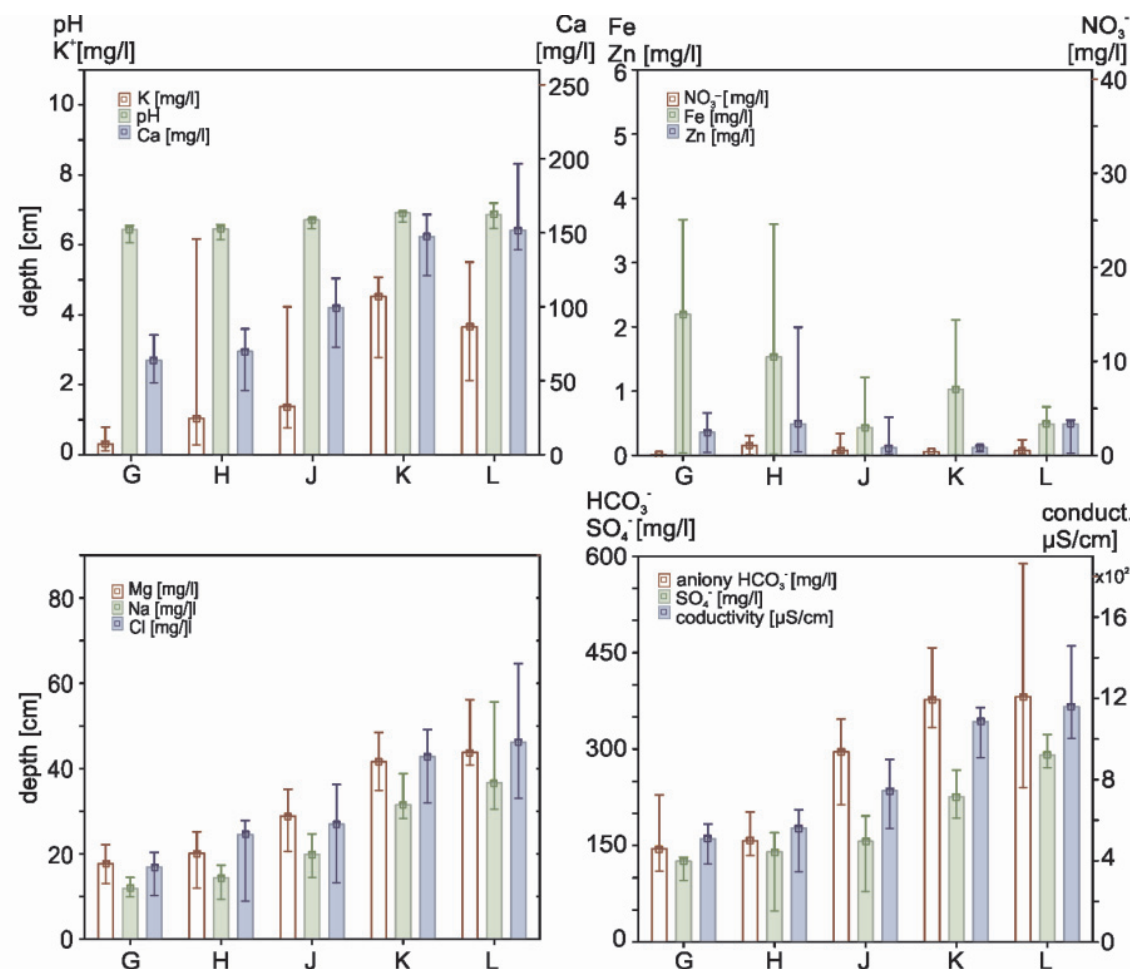

Fig. 7. Concentration variability of investigated features and chemical compounds in groundwater in cross-section G-L.

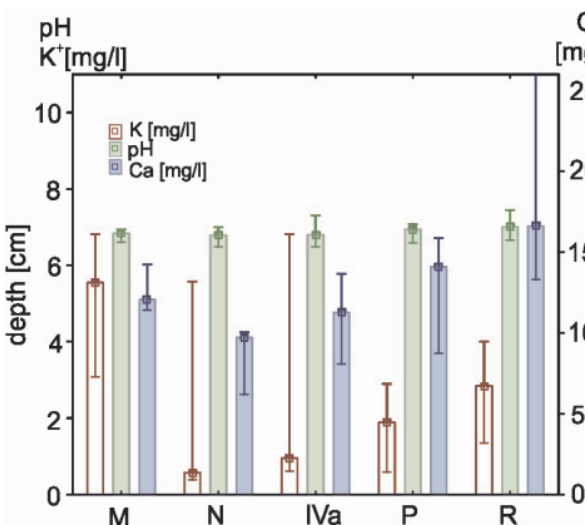

$\mathrm{Ca} \mathrm{Fe}$

$\mathrm{mg} / \mathrm{l}] \mathrm{Zn}[\mathrm{mg} / \mathrm{l}]$

$\mathrm{NO}_{3}^{-}$
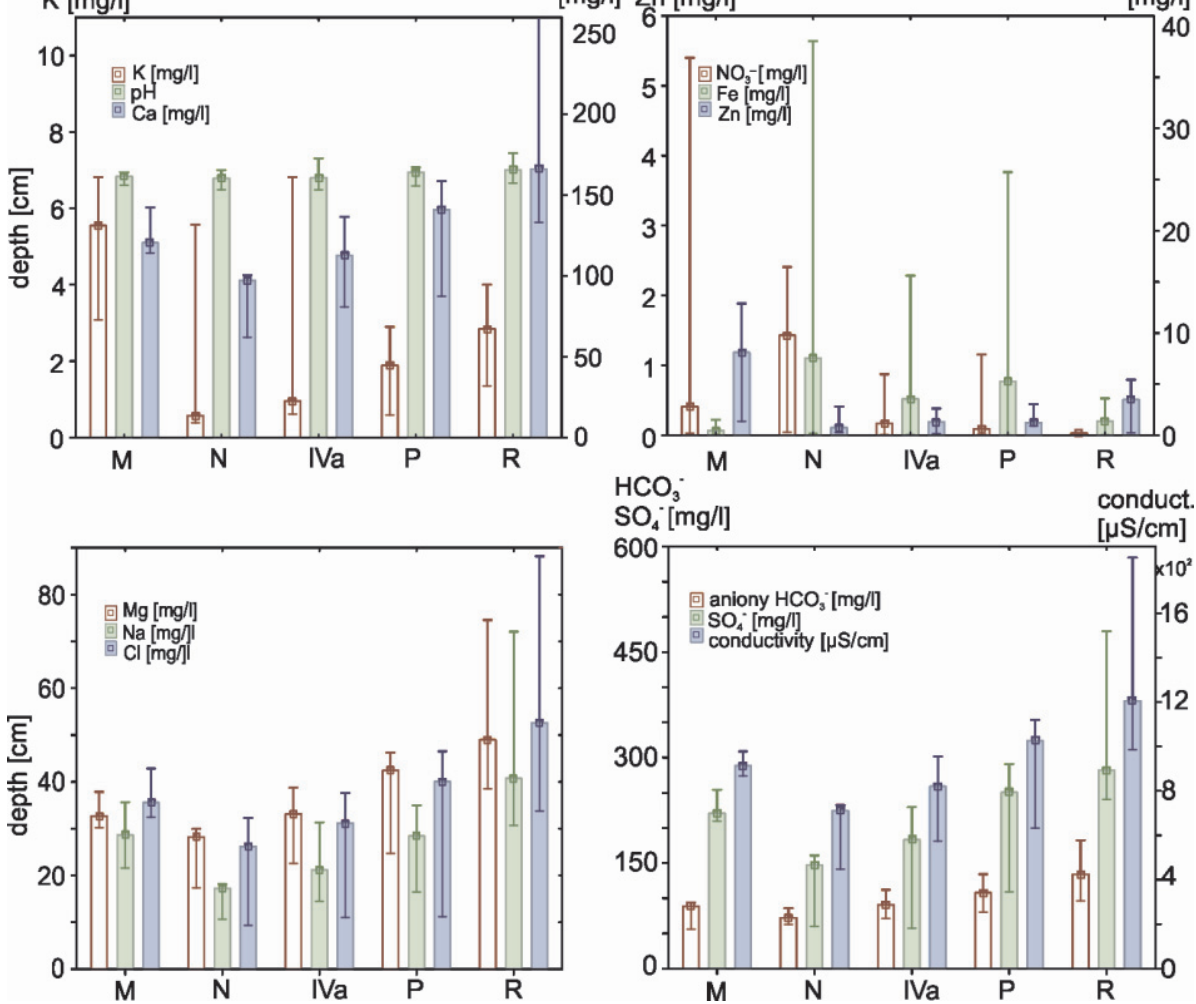

Fig. 8. Concentration variability of investigated features and chemical compounds in groundwater in cross-section M-R. 
the points (Fig. 6). The gradual decrease of zinc content from point $\mathrm{F}$ to $\mathrm{C}$ and the simultaneous increase of $\mathrm{Fe}$ content in the same direction are also typical. Nitrate content is strongly diversified between points and sampling periods. Fluctuations in the same point are from 0 to almost $40 \mathrm{mg} / \mathrm{l}$.
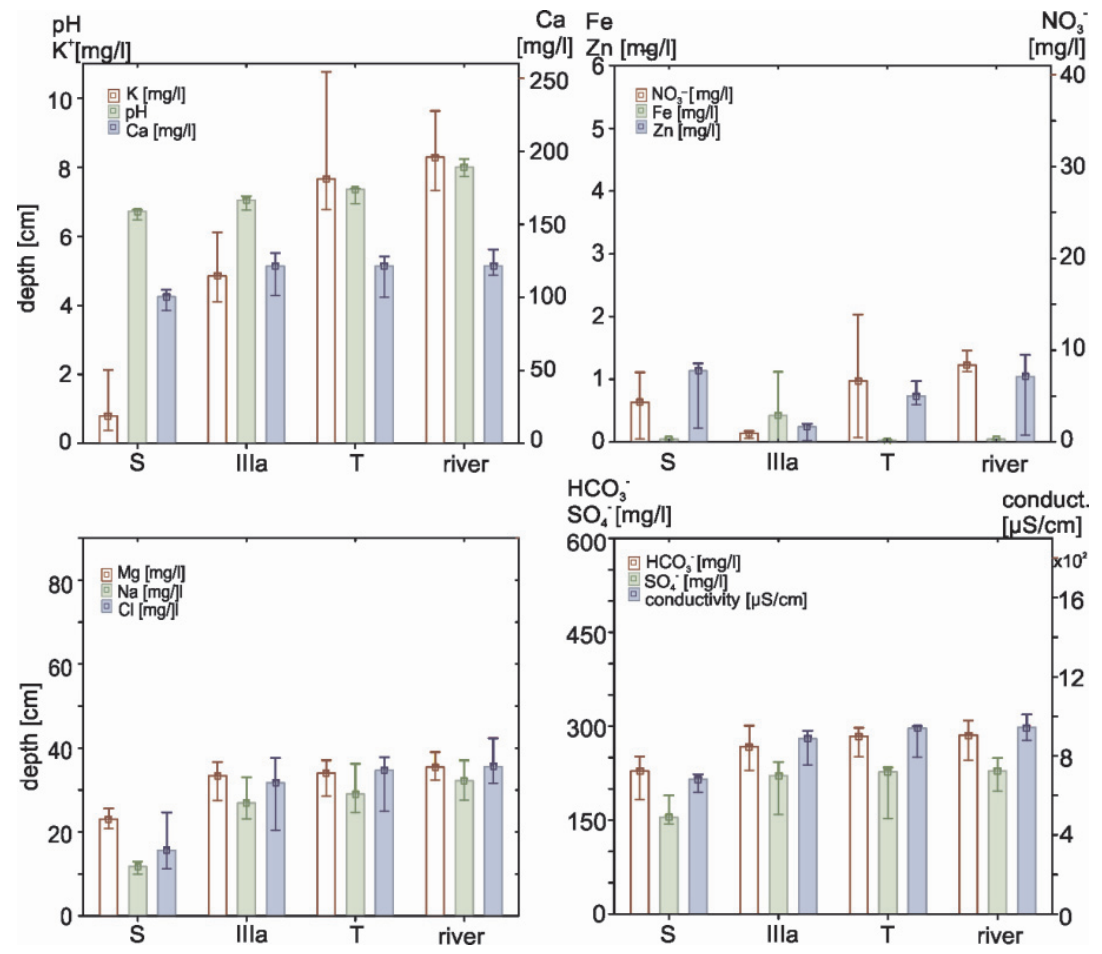

Fig. 9. Concentration variability of investigated features and chemical compounds in groundwater in cross-section S-T and in the river.

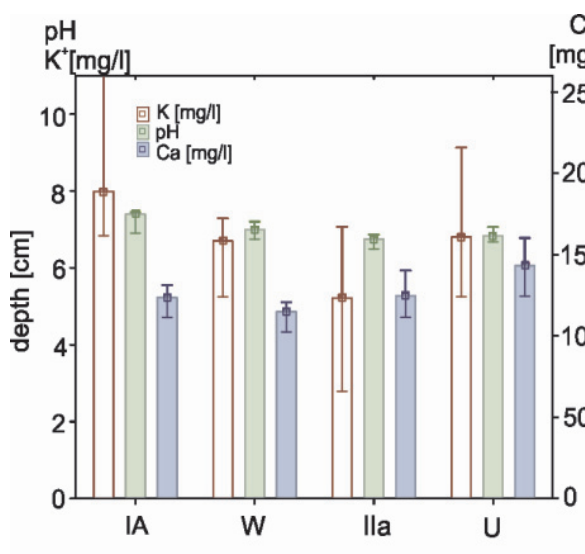

$\mathrm{Ca} \mathrm{Fe}$
$\mathrm{mg} / \mathrm{ll} \mathrm{Zn}[\mathrm{mg} / \mathrm{l]}$
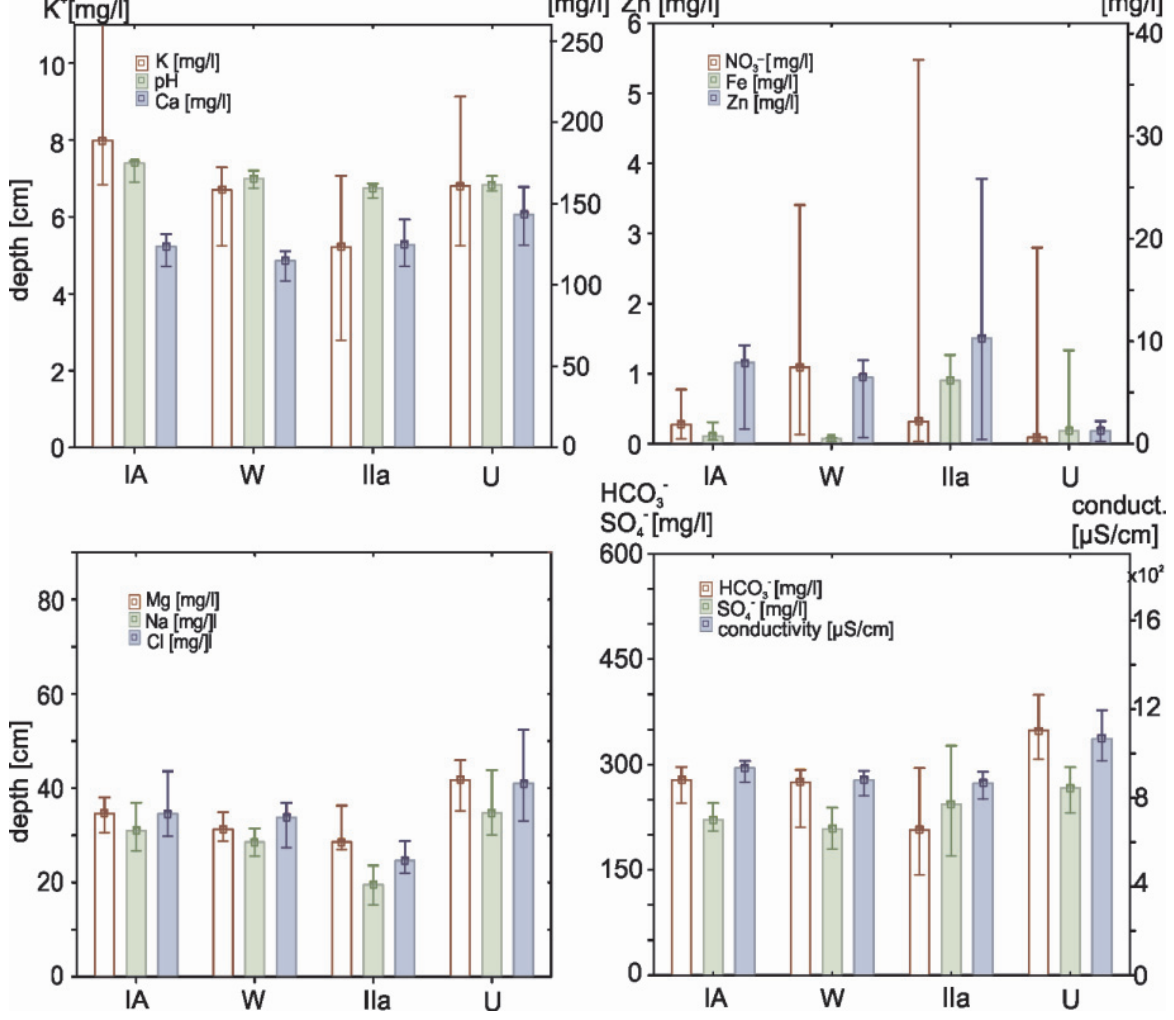

Fig. 10. Concentration variability of investigated features and chemical compounds in groundwater in cross-section IA-U. 
G-L section demonstrates the largest diversification of almost all analyzed components and chemical parameters (Fig. 7). The $\mathrm{pH}$ difference between the proximal part (K-L points) and the distal part (G-H) is about 0.5 units and is statistically significant. The difference in the content of $\mathrm{Ca}$ is higher because in the section of about 20 meters its content is reduced twice. $\mathrm{K}$ concentrations decrease even more (by three times), and at the extreme $G$ point of this section, at the distal edge of the bend, the concentrations of this element are even four times lower than the maximum. The average difference in the content of $\mathrm{Na}, \mathrm{Mg}$, and $\mathrm{Cl}$ between extremes of cross-sectional area is twofold, but the greatest decrease is noted in the central part of the section. Similarly, the concentration of bicarbonates changes and the average decrease in their concentration in the central section is by 2.5 times. The decrease in sulfate content is also greater than in C-F section, but it is also fast from L point near the river bank. Changes in conductivity between extreme points by approx. 1,100 to $500 \mu \mathrm{S}$ on average are convergent with the above changes. Changes in the content of nitrates (similar across the entire section) and zinc do not demonstrate such patterns. Fe concentrations, on the other hand, are as high as in the previous section in the distal direction of the bend.

$\mathrm{pH}$ does not show any significant variation in $\mathrm{M}-\mathrm{R}$ section through the central section of the bend (Fig. 8). Also, the differences in the analyzed components are also smaller than in the discussed profiles, which result from the fact that at point $M$ at the river bank the values of most of them increase with respect to the higher located point $\mathrm{N}$. Minimum content of $\mathrm{Ca}, \mathrm{K}, \mathrm{Cl}, \mathrm{Mg}$, $\mathrm{Na}$, sulfates, and bicarbonates is observed at point $\mathrm{N}$. Maximum values are noted at the riverbank in point $\mathrm{R}$. The decrease in content between these points is gradual but the differences in $\mathrm{Mg}$ and $\mathrm{Na}$ are approximately twofold. The difference in $\mathrm{K}$ content is higher, whereas the content of other components is lower. There is the least diversification of the content of bicarbonates, especially compared to the G-L section; they are also twice lower on average than in that section. The maximum content of other components at point $\mathrm{R}$ is close to maximum values recorded at point $F$ in the previously discussed section. The observed changes are reflected in the maximum conductivity of about 1,200 $\mu \mathrm{S}$ near the proximal edge and minimum conductivity of about $800 \mu \mathrm{S}$ at point $\mathrm{N}$. Increased Fe content is also noted between the proximal bank and point $\mathrm{N}$, and the simultaneous decrease in zinc content in the same section. The nitrate content is inconsiderable and similar throughout the section.

The comparison of analyzed components and parameters in groundwaters in the S-T section with river water shows that these values considerably differ from others at point $\mathrm{S}$ only (Fig. 9). At this point, the values for $\mathrm{pH}, \mathrm{K}, \mathrm{Ca}, \mathrm{Mg}, \mathrm{Na}, \mathrm{Cl}$, sulfates, and bicarbonates are the lowest. Conductivity, which in the river takes the value above $900 \mu \mathrm{S}$, also drops to about $700 \mu \mathrm{S}$ at this point. On the other hand, nitrate content at central point IIIa is the lowest. As in other sections, the maximum concentrations of $\mathrm{Fe}$ appear at the points where $\mathrm{Zn}$ content is the lowest. The concentrations of this element are relatively high in the river at about $1 \mathrm{mg} / \mathrm{l}$, while $\mathrm{Fe}$ content is about $0.1 \mathrm{mg} / 1$.

At points near the meander apex, $\mathrm{pH}$ values are characterized by relatively small diversification (Fig. 10). They have much higher values at point Ia in the channel. Also point IIa should be noted, which demonstrates the smallest concentrations among the examined compounds. As a result, it has the lowest conductivity values of around $900 \mu \mathrm{S}$, very close to the value for river water. In other points, the values are similar to those recorded in the S-T section. At the analyzed points, the content of nitrates is subject to very high and irregular fluctuations during the year, which are the largest at point IIa. At that point, the concentrations of $\mathrm{Fe}$ are also the highest, whereas at the other points they are much lower, similar to those occurring in river water.

\section{Discussion}

The analyzed groundwaters are characterized by considerable spatial variability of their chemical composition. The highest content of almost all chemical components is observed in the width zone of about $1 / 3$ the diameter of the bend, extending along its proximal section to the apex point. The highest content of macroions is usually approximately $20-25 \%$ higher than in river water. To the outside of the zone, their content rapidly decreases to much lower levels than those for river water. The lowest ones are even $100 \%$ lower than the content in river water. The area in the central part, where the gradient of these values is the greatest, is convergent with the area of the greatest fall of the water level. Such variability clearly indicates the inflow of river water to the proximal part of the bend. The most typical characteristic of waters in this section is the significantly increased content of $\mathrm{Ca}, \mathrm{Mg}, \mathrm{Na}, \mathrm{Cl}$, and sulfates, which is related to the high proportion of waters from zinc and lead ore mines in river water. These features facilitate the identification of the flux of river waters, i.e., the extent of the hyporeic zone, which in valleys of uncontaminated rivers is determined usually using more sophisticated techniques [13]. Therefore, the inflow of water is most intense in the zone near the river bank, but some river water flux is also through other parts of the river bend. This is indicated by approximately twice higher content of macroions in other parts of the bend than in points $\mathrm{A}$ and $\mathrm{B}$, which lie outside the direct inflow zone of river waters in this bend. If the values in these points are, however, compared to point OO, which represents waters that naturally drain the valley bottom, it is clear that they are also contaminated, and the difference in the macroion content between them is even two-fold. 
The diversification of chemical composition implies that river water is dispersed throughout the valley bottom at the beginning of the complex meander and the analyzed bend is its part [7]. The inflow of water into the proximal sections of both the bend and the entire meander is the most intense. The flow rate of waters is very slow because sediments are composed of medium- and fine-grained sand, and in many places there are deposits of silty sediments and silty sands that significantly reduce the rate of water migration. The filtration rate of $10^{-4}-10^{-5} \mathrm{~m} / \mathrm{s}$ is typical of such sediments. Its value has been confirmed by trial determination of migration rate with a solution of sodium chloride introduced at point F. The assessed migration rate was very uneven, and in the initial section it was lower by even two orders of magnitude than near the apex where it was much faster, with a value of approx. $10^{-2} \mathrm{~m} / \mathrm{s}$. Although the obtained average value is consistent with the theoretical value, its variability indicates the importance of the diversity of the mechanical composition of sediments, which is of considerable significance due to the calculation of water flow models on such a scale [14]. The very slow rate of water migration in the proximal bend section between points $\mathrm{F}$ and $\mathrm{R}$ converged with the maximum content of macro-ions and conductivity at these points. Such values are higher than in river water; they may be associated with evapotranspiration and episodes of inflow of more polluted waters discharged from mines periodically. It is clear that plants also have a very significant impact on the amount of water drawn. This is evidenced by a considerable decrease in water level during the growing season in spite of greater rainfall during this period than in the winter (Fig. 3). This is due to the intensive production of biomass by the overgrowth of reed and sedge shrubs. Plants also have the ability to pick up only certain ingredients selectively with water and thus concentrations of the other elements may increase in shallow groundwaters. On the other hand, a decrease in concentrations in sections toward the distal edge of the bend results in dilution by rainwater as greater amounts of rainwater entail a larger proportion of cleaner rainwater. If the river water inflow near the distal bank is observed (as evidenced by relatively faster pumping of water at points $\mathrm{C}$ and $\mathrm{M}$ ), then the increase in the content of macroions can be also noticed at these points.

The changeable chemical composition of examined waters is not a function of physical processes only. As a result of bacterial activity, oxygen is depleted in river waters flowing through the ground at a rate inversely proportional to the rate of water flow. The consumption of dissolved carbon compounds at a further distance intensifies denitrification processes, resulting in reduced amounts of nitrate compounds. This is associated with $\mathrm{CO}_{2}$ production, which leads to a relatively low concentration of bicarbonates maintained in groundwaters. These processes are then replaced by sulfate degradation and sulfide formation. Such variability causes the formation of biogeochemical zones, as shown in hydrological models [10]. The consequence is the dissolution of iron compounds under reducible conditions and the observed increase of its concentration alongside an increase in transportation distance. Iron precipitates in the places where groundwaters flow out onto the surface in the valley of the Biała Przemsza River, and its concentrations even exceed $10 \%$. Heavy metals such as zinc, in turn, undergo sorption near the riverbank, thus causing secondary enrichment of sediment layers, mainly at the usual depth of the water table [7].

Assuming a uniform composition of alluvia, water exchange in the hyporheic zone in the river bend depends on the slope of the valley bottom and the sinuosity of the river. Increases in these parameters causes reduced exchange of hyporheic waters [15]. These parameters influence the distance of water flow in the river bend sediments. Hydrological models indicate that the time of water flow through the river bend in sandy alluvia may amount to several years and it is the longest in the bends of lower sinuosity [16], like the analyzed bend. The exchange of waters in such a bend is relatively the fastest along the channel and it becomes slower as the distance from the proximal bank increases. Thus, this part of the bend has a strong tendency to form water exchange zones of similar intensity roughly parallel to the course of the channel [8]. Its effect can be also observed in the analyzed bend as a clearly marked zone of chemical composition. The irregular fall of the water level in the analyzed bend is an unpredictable characteristic of hydraulic hyporheic water exchange models. It causes a large concentration gradient of many macroions in its central section, induced by both the stability of the shape of the bend itself over decades and by flows whose fluctuations are unnaturally reduced due to the relatively stable discharge of mine waters [7]. The formation of uneven falls in the level of groundwaters contributes to the occurrence of silt particles in sandy sediments. The clogging of sediments with these particles is possible, at least in selected sections. This makes the water table tense. For this reason, an attempt to drill sediments in the zone of the largest fall of the groundwater level between points Ia and IIa was unsuccessful.

The patterns of spatial diversification of the chemical composition of river waters flowing into the analyzed bend show that a relatively narrow near-bank zone is of key importance to the transformation of the chemical composition of waters in fine-grained alluvia. In the examined bend, it covers about $1 / 3$ of the area in its proximal section. It is the strip where numerous chemical compounds and elements transported by the river are accumulated. Studies on the diversification of water and sediment contamination in this zone in the losing section of the Biała Przemsza River indicate that it converges with the zone of relatively intensive formation of flood dykes [7]. Nitrate compounds undergo radical reduction in the near-bank part of the hyporheic zone, which is evidenced by a comparison of their content in the river and in groundwaters near the river bank. The low content of these compounds even 
in piezometers at a distance of $1 \mathrm{~m}$ from the river bank suggests a rapid reduction in their quantities. This is facilitated by long periods of water migration in poorly permeable formations [17]. When leaving the hyporheic zone, mainly near the apex of the analyzed bend, these waters will not contain these compounds, yet the real impact on reducing their load in the river may be visible in a section of a length of many kilometers. The exact length of such a section is difficult to estimate without conducting studies on channel sediments that have a considerable impact on the transformation of these compounds [18].

Experimental research on the diversification of chemical composition of hyporheic waters, particularly in meander bends, is rare. It is generally carried out in groundwater reservoirs with considerable presence of gravel formations because they are more abundant in water and much more strongly related to river water $[18$, 19]. The assessment of such an exchange is basically based on hydraulic models that have been considerably developed in recent years $[8,14,15]$. The newest models are more advanced, which is evidenced by the fact that more variables affecting hyporheic water flow are taken into account. To a limited extent, such models are verified on the basis of laboratory experiments or field tests. Limitations in their use are due to the complex geological structure of sediments affecting the directions and volume of water flow that imply the variable migration time of these waters within different areas of the hyporheic zone. The load of chemicals undergoing transformation in groundwaters on rivers is also variable, depending on seasons. Complicating factors include the morphology of the floodplain, and in particular the presence of oxbow lakes, which can be the preferred paths of water flow of varying intensity in case of changing water levels [15]. Therefore, modeling assumes in advance only an approximation of the existing reality, which may, however, be difficult to estimate in fine-grained alluvial sediments. Current research showing that the water table within the bend area need not have a uniform fall and its inclination may be far from assumptions is one example. This may be related to the transported material in a form of suspension or its quality but also to the history of fluvial processes evolution and diagenetic processes in sediments, which are currently far from being quantified. Failure to take the majority of these factors into consideration in models may lead to estimates that do not reflect reality, or even their error may be difficult to estimate. With the higher heterogeneity of sediments, modeling becomes less accurate in reflecting the reality, and the knowledge of the role of biogeochemical processes is limited to qualitative rather than quantitative recognition.

\section{Conclusions}

The contamination of Biała Przemsza River waters made it possible to identify to what extent these waters are supplied by groundwaters in a small bend in the middle course of the river. These groundwaters are characterized by the formation of a biogeochemical zone associated with the varying intensity of water inflow into different sections of the bend. The proximal section of the bend in the zone of about $1 / 3$ of its width is supplied with greatest intensity. It is characterized by higher concentrations of the majority of macroions than in river waters. Beyond it, a noticeable decrease in macroion content is noted in the central part of the bend. These characteristics are most diversified in sections in the upper half of the bend and the diversification decreases toward the bend apex. In the central part, the fall of the water level is distinctly larger than in other sections of the bend. It increases toward the apex to about $40 \mathrm{~cm}$ near the channel. The lowest content of macroions in groundwaters in the distal zone is caused by longer migration times and the dilution of precipitation waters. Outside the bend there is a valley bottom area supplied with river water from the upper part of the valley. Considering that the content of macroions is twice lower, it may be assumed that the impact of river waters is relatively smaller there. The discussed sediments on the valley bottom are under the influence of river waters and form the hyporheic zone of the Biała Przemsza River. The rate of water exchange in this zone is very slow due to the deposition of sandy and silty sediments. It may take even several years and contribute to the transformation of nitrates, sulfates, and iron mobilization under reduction conditions.

\section{Acknowledgements}

This research was conducted as part of National Science Center Project No. 2012/05/B/ST10/00235 and statutory research grant no. 11.11.140.017.

\section{Conflict of Interest}

The author declares no conflict of interest.

\section{References}

1. KRAUSE S., HANNAH D.M., FLECKENSTEIN J.H., HEPPELL C.M., KAESER D., PICKUP R., PINAY G., ROBERTSON A.L., WOOD P.J. Inter-disciplinary perspectives on processes in the hyporheic zone. Ecohydrology, 4, 4819, 2011.

2. BOULTON A.J., DATRY T., KASAHARA T., MUTZ M., STANFORD J.A., 390 Ecology and management of the hyporheic zone: stream-groundwater interactions of running waters and their floodplains. J. North Amer. Benthol. Soc., 29, 26, 2010.

3. BOANO F.R., REVELLI L., RIDOLFI L. Bedform induced hyporheic exchange with 393 unsteady flow. Advances in Water Resources, 30, 148, 2007. 
4. MERILL L., TONJES D.J. A review of the hyporheic zone, stream restoration and means to enhance denitrification. Critical Reviews in Environmental Science and Technology, 44, 2337-2379, 2014.

5. CARDENAS M.B. Stream-aquifer interactions and hyporheic exchange in gaining and 398 losing sinuous streams. Water Resources Research, 45, W06429, 2009.

6. WOESSNER W.W. Stream and fluvial plain ground water interactions: rescaling 400 hydrogeologic thought, Ground Water, 38, 423, 2000.

7. ALEKSANDER-KWATERCZAK U., CISZEWSKI D. Pollutants dispersal in groundwater and sediments of gaining and losing river reaches affected by metal 404 mining. Environmental Earth Sciences, 75, 95, 2016.

8. REVELLI R., BOANO F., CAMPOREALE C., RIDOLFI L. Intra-meander hyporheic 406 flow in alluvial rivers, Water Resources Research, 44, W12428, 2008.

9. KIEL B.A., CARDENAS M.B. Lateral hyporheic exchange throughout the 408 Mississippi River network. Nature Geoscience 7, 413-417, 2014

10. CISZEWSKI D. Hydrodynamiczne procesy rozpraszania osadów zanieczyszczonych metalami ciężkimi w korytach wybranych rzek Górnego Śląska. Prace Nauk UŚ 1805, Studia et Dissertationes, 23, 7, 2000.

11. CISZEWSKI D., ALEKSANDER-KWATERCZAK U. Contrasting sediment and 413 water chemistry indicates the extent of the hyporheic zone in a polluted river system. Geology, Geophysics and Environment, 43, 151, 2016.

12. CARUK M., DRUŻYŃSKA E., JARZAॄBEK A. Wybrane aspekty jakości wód Białej 416 Przemszy. Środowisko, Czasopismo Techniczne, 106, 1, 2009.
13. KALBUS E., REINSTORF F., SCHIRMER M. Measuring methods for groundwater418 surface water interactions: a review. Hydrology and Earth System Science, 10, 873, 2006.

14. BOANO F., DEMARIA A., REVELLI R., RIDOLFI L. Biogeochemical zonation due to intrameander hyporheic flow. Water Resources Research, 46, W02511, 2010.

15. GOMEZ J.D., WILSON J.L., CARDENAS M.B. Residence time distributions in 423 sinuosity-driven hyporheic zones and their biogeochemical effects. Water Resources Research, 48, W09533, 2012.

16. CARDENAS M.M. The effect of bend morphology on flow and timescales of surface 426 water-groundwater exchange across pointbars. Journal of Hydrology, 362, 134, 2008.

17. ZARNETSKE J.P., HAGGERTY R., WONDZELL S.M., BAKER M.A. Dynamics of nitrate production and removal as a function of residence time in the hyporheic zone, 430 Journal of Geophysical Research, 116, G01025, 2011.

18. OSENBRÜCK K., WÖHLING T., LEMKE D., ROHRBACH N., SCHWIENTEK M., LEVEN C., ALVAREZ C.C., TAUBALD H., CIRPKA O.A. Assessing hyporheic exchange and associated travel times by hydraulic, chemical and isotopic monitoring at the Steinlach test Site, Germany. Environmental Earth Sciences, 69, 359, 2013.

19. TRAUTH N., SCHMIDT CH., VIEWEG M., OSWALD SE., FLECKENSTEIN J.H. Hydraulic controls of instream gravel bar hyporheic exchange and reactions. Water 438 Resources Research, 51, 2243, 2015. 
